\title{
Physical rehabilitation criteria throughout the stages of therapeutic exercises program for functional disabilities resulting from accident injuries. \\ ${ }^{{ }^{*}}$ Dr Mustafa Ibrahim Ahmed **Dr Ahmed Refaat Raya
}

Globally, an estimated 650 million people live with some form of disability, $80 \%$ of whom live in low-income countries (27). The number of people with disabilities in those countries who will need rehabilitation is expected to reach 125 million by 2035 (11). This number is increasing due to the increase in chronic diseases, accidents (falls, car accidents, injuries, violence and wars), life progress in medicine and population aging (27). This resulted in the loss of 76 million years of healthy life by calculating disability periods (9), (18). One of the most important risk factor to be adjusted to stop this increase in disability is accidents. Most accidents are caused by car or trains or traffic accidents (28).

Because of the nature of the injury and the extensive surgical intervention, soft tissue disease appears and may limit the return of the patient to the previous job level (5) (12) (13) (14) (20) (29). As a result of disability and functional limitations that remains after injury, and surgical intervention procedures for a long period of time, even after complete healing of the stabilized bone (20) (21). Approximately, half of broken leg injured, treated surgically at first level when had some remaining disability for 12 months after injury, and more than $20 \%$ of the injured surgically treated for lower limb fractures were unable to return to work for 3 years after injury. Moreover, only $72 \%$ of injured treated for lower limb fractures at level 1 were able to return to work after 12 months post-injury. These results confirm that, one year after surgery, the opportunity to

(*) *Assistant Professor of Sports Injuries, Department of Sport Health Sciences, Faculty of Physical Education, Assiut University, Egypt.

** Lecturer of Exercises and Gymnastics, Department of Exercises and Gymnastics Training, Boys Faculty of Physical Education, Alexandria University, Egypt. 
return to function and work is reduced (6).

These different types of injuries and functional disabilities affect the quality of life and families of persons with disabilities. As people with disabilities are limited in various areas including physical and social performance, mental health and delay in return to work or study (19). The results of studies revealed that the return to normalcy has been a complex, difficult and long-term process for injured suffering from traffic accidents (23).

In addition, the importance of rehabilitation exercises has increased in recent times, so that some therapeutic schools rely entirely on the treatment of physical aberrations and stadium injuries without intervention of any other factors such as medication, injections and refractories, except in cases where surgical intervention is required. Furthermore, rehabilitation exercises take most of the importance, if not the most important to bring the players back to the stadiums and bring the non-athletes back to day-today activities after surgery and preparation for surgeries (2).

\section{Objectives:}

1. Design the physical rehabilitation standards during the stages of the program of therapeutic exercises for functional disabilities resulting from accident injuries.

2. Determine the indicators of measuring the physical rehabilitation standard during the stages of the program of therapeutic exercises for functional disabilities resulting from accident injuries.

Research Questions:

First: What are the criteria for physical rehabilitation during the stages of the program of therapeutic exercises for functional disabilities resulting from accident injuries?

Second: What are the indicators of measuring physical rehabilitation standards during the stages of the program of therapeutic exercises for functional disabilities resulting from accident injuries?

\section{Procedures:}

First: human Filed: The size of the research sample 50 faculty members divided into 15 members of the teaching staff specializing in physical rehabilitation of the departments of sports and health sciences, 15 members of the teaching staff of the training department of physical education colleges, 10 members of the faculty of natural medicine and 10 members Faculty of Orthopedic Surgery, Faculty of Medicine, Alexandria University. 
Second: Spatial Field: Faculties of Physical Education, Department of Natural Medicine and Department of Orthopedic Surgery, Faculty of Medicine, Alexandria University.

Third: time field: The research procedures were applied in the period from: $03 / 12 / 2017$ to $26 / 3 / 2018$. The previous studies were reviewed in the period from: 03/12/2017 to $30 / 12 / 2017$. Then, the questionnaire form was prepared from: 01/01/2018 to 20/01/2018, then applied the questionnaire form by presenting it to the experts and processing it statistically from 01/03/2018 to 26/03/2018.

Basic Study:

Determination of the age range of the injured: the age range between 20 to 50 years.

Determination the causes of the accident: accidents (falls, traffic accidents, serious sports injuries).

Description of injury: Oblique fractures of the femoral bone, fractures of the head of the femur and/or leg or neck of the head of the bone, crumbled fractures, multiplied fractures, patella fractures and fractures accompanied by partial or total rupture of ligaments or cartilage of the same man. This injury is categorized Multiply-injured with inflammation and roughness in the knee joint with no neurological deficit in the lower limb and the need for surgical intervention.

Description of the traditional physical therapy adopted after surgery: After surgery and stabilization, the patient begins to process physical therapy, which usually lasts for two to four months, from 3 to 5 sessions of physical therapy with the conduct of 4 constant exercises. According to the assessment of patients for their condition did not feel noticeable improvement and felt severe disability. Physical therapy also has failed to put them on the path to return to their functional state.

Monitoring of occupational disability due to accident injuries and after the completion of the stages of surgical intervention and traditional physical therapy: weakness and irritation of the thigh muscles that result in the abnormal walking pattern of the "limp walking model", lack of function related to walking with low walking tolerance, painless walking, Knee extension in the middle-to-end axis, weakness of the quadriceps muscle, frontal knee pain, progressive bursitis, stiffness of the hip and knee joint, lack of endurance, 
inability to perform more advanced skills, Hobbies) or you may need to be modified in order to be performed, change the case of load weight and inability to run or jump or use stairs, and these have resulted in restrictions on disabilities and functional in daily life activities.

Formulation of the objectives of the proposed training program for the rehabilitation of accident injuries: After reviewing the previous studies and studies conducted by the researchers and monitoring the degrees of disability and symptoms, the objectives of each stage were formulated based on the remaining functional disabilities of the impact of the accident and according to the training exercises that can be disabled with functional performance.

\section{Design of the} Qualifying Criteria for the proposed training program for the rehabilitation of accident injuries: After completing the formulation of the proposed rehabilitation objectives for each stage based on the previous research review, the researchers set criteria for transition from rehabilitation stage to the next stage. These criteria allow the patient to move on to the next stage after achieving them.

Determination of criteria for measuring and verifying criteria: After the criteria for transition have been established, indicators have been developed for measuring and verifying the criteria so as to facilitate their application within the capabilities of the disabled and the capabilities of the physical rehabilitation specialist.

Verification of the validity of the form (Appendix 1): The validity of the physical qualification criteria and their verification indicators were calculated during the stages of the program of therapeutic exercises for functional disabilities resulting from accident injuries using the Alpha-Cronbach method and the half-way method using the Spearman Brown coefficient. It showed out that the criteria and indicators are of high-stability.

Verification of the validity of the questionnaire (Appendix 1): The validity of the physical qualification criteria and their 
verification indicators during the stages of the program of therapeutic exercises for occupational disabilities resulting from accident injuries was calculated by comparing the differences between the higher and lowest quartiles. The value of the honesty factor (0.85) which ensures that questionnaire under research measures what is set for it, and it can distinguish between different levels.

Questionnaire for qualification criteria and measurement indicators and methods of verification for the program of training exercises for accident injuries to experts (Annex 2): The questionnaire was designed in its final form after confirming the validity of the form, presenting it to the experts, collecting the forms and electronically unloading them and then processing them statistically.

Statistical treatments: The appropriate statistical treatments were used as shown in the statistical tables.

Presentation and discussion of findings: The views and experiences of a physiotherapist indicated that the most likely factors that may affect the utilization of physiotherapy services are the lack of skills and knowledge of physiotherapists and the lack of criteria for assessing the rehabilitation of the injured. It is therefore important to find treatments and criteria that can enhance motor function after injuries, disabilities and reduced functional capacity. The statistical tables, Table (1) (2) (3) (4) (5) indicate the consensus of the experts on the safety and relevance of the physical rehabilitation criteria and the indicators of verification proposed in the current research and that are commensurate with the objectives of each stage of rehabilitation, which achieves research objectives and answer the questions raised. 
Table (1)

Frequency, percentage and statistical indications of the initial qualification stage

\begin{tabular}{|c|c|c|c|c|c|c|c|c|c|c|c|}
\hline \multirow{2}{*}{$\stackrel{\mathscr{C}}{\mathscr{\bullet}}$} & \multirow{2}{*}{ 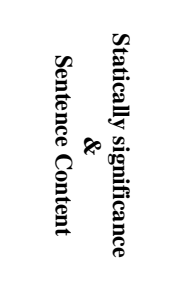 } & \multicolumn{2}{|c|}{$\precsim$} & \multicolumn{2}{|c|}{ 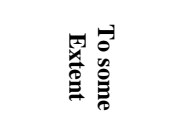 } & \multicolumn{2}{|r|}{ z } & \multirow{2}{*}{ 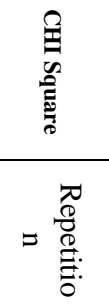 } & \multirow{2}{*}{ 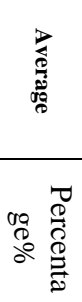 } & \multirow{2}{*}{ 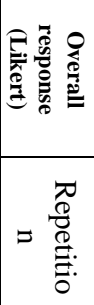 } & \multirow{2}{*}{ 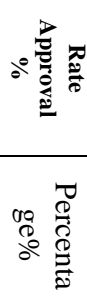 } \\
\hline & & $=\frac{\underset{0}{0}}{\stackrel{0}{0}}$ & 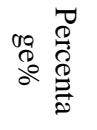 & 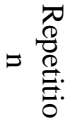 & 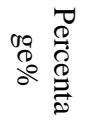 & 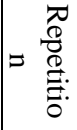 & 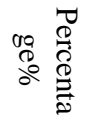 & & & & \\
\hline \multirow{3}{*}{ 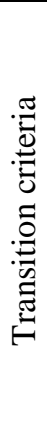 } & $\begin{array}{l}\text { Improves the } \\
\text { fixed strength } \\
\text { of the lower } \\
\text { limb muscles. }\end{array}$ & $\varepsilon \wedge$ & $97 .$. & $r$ & $\varepsilon . \cdots$ & - & $\because \cdots$ & $* \varepsilon r, T r$ & r.97 & Yes & $9 \wedge .$. \\
\hline & $\begin{array}{l}\text { Improve the } \\
\text { motor range to } \\
\text { flex the lower } \\
\text { limb joint. }\end{array}$ & $\varepsilon \wedge$ & $97 .$. & 1 & $r .$. & 1 & $r .$. & 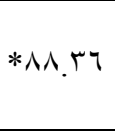 & r. $9 \leq$ & Yes & $q \vee .$. \\
\hline & $\begin{array}{l}\text { Load at least } \\
25 \% \text { of the } \\
\text { body weight } \\
\text { of the } \\
\text { infected leg }\end{array}$ & rq & 199.09 & 7 & IT.YE & $\varepsilon$ & 1.17 & * $\leqslant V . T$ & Y.VI & Yes & 10.11 \\
\hline \multirow{3}{*}{ 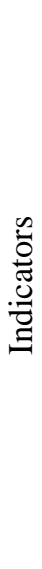 } & $\begin{array}{l}\text { Raise the leg, } \\
\text { angle less than } \\
45 \text { degrees } \\
\text { against the } \\
\text { processor hand } \\
\text { and hold } 10 \mathrm{w} .\end{array}$ & $\varepsilon V$ & $9 \leq \ldots$ & $r$ & $7 .$. & - & $\because \cdots$ & $* r \wedge . \vee T$ & r. $9 \leq$ & Yes & $9 V . .$. \\
\hline & $\begin{array}{l}\text { Increase the } \\
\text { angle of the } \\
\text { joints by } 5 \\
\text { degrees by } \\
\text { the } \\
\text { geonometer. } 0 \text {. }\end{array}$ & $\varepsilon \wedge$ & $9 \vee .97$ & - & $\because \cdots$ & 1 & $r . \varepsilon$ & $* \leqslant 0.1$ & r.97 & Yes & $9 V .97$ \\
\hline & $\begin{array}{l}\text { Ability to load } \\
\text { at least } 25 \% \text { of } \\
\text { the weight on } \\
\text { the medical } \\
\text { scale. }\end{array}$ & $\leqslant 1$ & Ar... & 0 & $1 \ldots$ & $\varepsilon$ & ^... & r.r. & $r . V \varepsilon$ & Yes & $\Lambda V_{.}$. \\
\hline
\end{tabular}

A significant Chi Square at level 0.05 where the significance level 0.050 .05 at the degree of freedom $2=5.99$, the degree of freedom $1=3.84$

Likert scale: average weight: - 1.00-1.66 (no), 1.67-2.33 (to some extent), 2.34-3.00 (yes) 
Table (1) for frequency, percentage and statistical indications of physical qualification criteria and their verification indicators for the initial qualification phase showed significant differences between the responses and these values for a significant CI at level 0.05 in all physical qualification criteria and verification indicators. Approval percentage is between $(85.71 \%$ to $98.00 \%)$. The table shows that the three physical rehabilitation criteria (improvement of the fixed strength of the lower limb muscles, improving the motor range of knee flexion, loading at least $25 \%$ of the body weight on the infected leg) are specific, easily measurable, accurate and proportional to functional disability at that stage. The objectives of the first stage are achieved, and the measurement indicators are easy to apply and have the degree to which the therapist can rely on the decision to move to the next stage. The body weight load at that stage is consistent with the results of recent studies recommending the need for early loading, which has been tested with patients with the same degree (1) (3).

Table (2)

Frequency, percentage and statistical significance of the second qualification stage

\begin{tabular}{|c|c|c|c|c|c|c|c|c|c|c|c|}
\hline \multirow{2}{*}{ Sr. } & \multirow{2}{*}{$\begin{array}{c}\text { Statically } \\
\text { significance } \\
\& \\
\text { Sentence } \\
\text { Content }\end{array}$} & \multicolumn{2}{|r|}{$\stackrel{8}{8}$} & \multicolumn{2}{|c|}{ 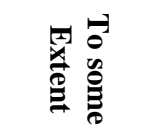 } & \multicolumn{2}{|c|}{ z } & \multirow{2}{*}{ 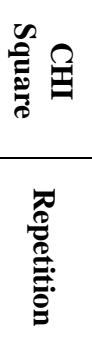 } & \multirow{2}{*}{ 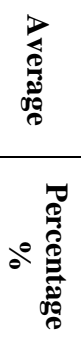 } & \multirow{2}{*}{ 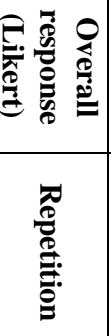 } & \multirow{2}{*}{ 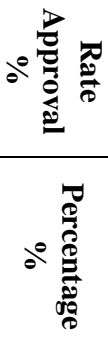 } \\
\hline & & 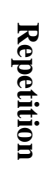 & 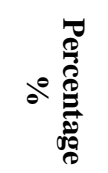 & 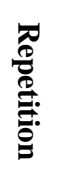 & do & 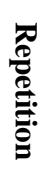 & 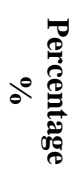 & & & & \\
\hline 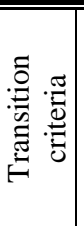 & $\begin{array}{l}\text { Improves } \\
\text { the fixed } \\
\text { strength of } \\
\text { the lower } \\
\text { limb } \\
\text { muscles. }\end{array}$ & 0 . & $1 \ldots \ldots$ & . & $\because \cdots$ & $\cdot$ & $\because \cdots$ & $\because \cdots$ & $r .$. & Yes & $1 \ldots \ldots$ \\
\hline
\end{tabular}


Follow Table (2)

Frequency, percentage and statistical significance of the second qualification stage

\begin{tabular}{|c|c|c|c|c|c|c|c|c|c|c|c|}
\hline \multirow{2}{*}{ Sr. } & \multirow{2}{*}{$\begin{array}{c}\text { Statically } \\
\text { significance } \\
\& \\
\text { Sentence } \\
\text { Content }\end{array}$} & \multicolumn{2}{|r|}{$\stackrel{R}{8}$} & \multicolumn{2}{|c|}{ 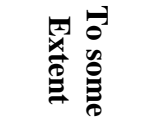 } & \multicolumn{2}{|c|}{ Z } & \multirow{2}{*}{ 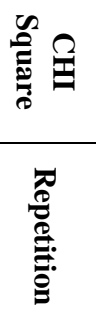 } & \multirow{2}{*}{ 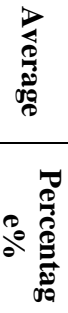 } & \multirow{2}{*}{ 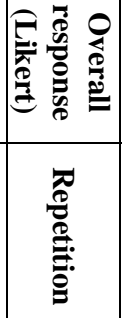 } & \multirow{2}{*}{ 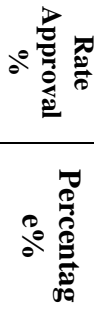 } \\
\hline & & 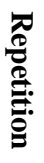 & คे & 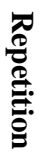 & จे & 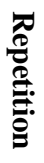 & จุ & & & & \\
\hline & $\begin{array}{c}\text { Improved } \\
\text { motor range for } \\
\text { joint flexion } 10 \\
\text { degrees. }\end{array}$ & 0 . & $1 \cdots \cdots$ & - & $\because \cdots$ & • & $\because \cdots$ & $\because \cdots$ & $r .$. & Yes & $1 \ldots$ \\
\hline & $\begin{array}{l}\text { Load at least } \\
50 \% \text { of the } \\
\text { body weight on } \\
\text { the infected leg }\end{array}$ & $\varepsilon r$ & $\wedge \varepsilon . \cdots$ & $\varepsilon$ & $\wedge . \cdots$ & $\varepsilon$ & $\wedge . \cdots$ & *OV.VT & Y.VT & Yes & $\wedge \wedge .$. \\
\hline \multirow{2}{*}{ 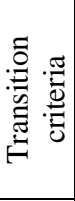 } & $\begin{array}{c}\text { Improved } \\
\text { stable balance } \\
\text { on infected leg. }\end{array}$ & $\leqslant 1$ & Ar... & 0 & $1, \cdots$ & $\varepsilon$ & ^... & *or.r. & Y.V $\mathrm{s}$ & Yes & Av... \\
\hline & $\begin{array}{c}\text { Improved } \\
\text { walking with } \\
\text { reduced } \\
\text { auxiliary tools. }\end{array}$ & 0 . & $1 \cdots \cdots$ & - & $\because \cdots$ & · & $\because \cdots$ & $\because \cdots$ & $r .$. & Yes & $1 \ldots$ \\
\hline 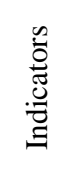 & $\begin{array}{l}\text { Raise the leg } \\
\text { angle of } 45 \\
\text { degrees against } \\
\text { the therapist } \\
\text { hand and } \\
\text { fastness } 15 \mathrm{~s}\end{array}$ & $\leqslant \wedge$ & $9 \vee .97$ & 1 & $r . \varepsilon$ & · & $\because \cdots$ & $* \leqslant 0.1$ & $r .91$ & Yes & 91.91 \\
\hline \multirow{4}{*}{ 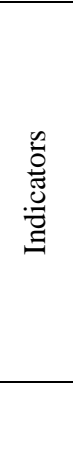 } & $\begin{array}{l}\text { Bend the joint } \\
\text { angle by } 10 \\
\text { degrees with the } \\
\text { geonometer. }\end{array}$ & $\leqslant 9$ & $91 .$. & 1 & r... & • & $\because \cdots$ & $* \varepsilon\rceil . \wedge$ & r.91 & Yes & $99 .$. \\
\hline & $\begin{array}{l}\text { Load at least } \\
50 \% \text { of the } \\
\text { weight on the } \\
\text { medical scale. }\end{array}$ & $\leqslant r$ & ᄉฯ... & 0 & $1 . \cdots$ & r & $\varepsilon . \cdots$ & *ฯ. & r.Ar & Yes & $91 .$. \\
\hline & $\begin{array}{l}\text { Stability and } \\
\text { standing on the } \\
\text { foot of the } \\
\text { infected leg } \\
\text { with the eyes } \\
\text { closed for } 10 \mathrm{~s}\end{array}$ & 0 . & $1 \cdots \cdots$ & - & $\because \cdots$ & • & $\because \cdots$ & $\because \cdots$ & $r .$. & Yes & $1 \cdots$ \\
\hline & $\begin{array}{l}\text { Walk forward } \\
\text { with one crutch } \\
\text { for } 10 \text { meters. }\end{array}$ & 0 . & $1 \cdots$ & • & $\because \cdots$ & • & $\because \cdots$ & $\because \cdots$ & $r .$. & Yes & $1 \ldots$ \\
\hline
\end{tabular}

*A significant Chi Square box at level 0.05 where the significance level 0.050 .05

at the degree of freedom $2=5.99$, the degree of freedom $1=3.84$ 
Table (3)

Frequency, percentage and statistical significance of the third qualifying stage

\begin{tabular}{|c|c|c|c|c|c|c|c|c|c|c|c|}
\hline \multirow{2}{*}{ Sr. } & \multirow{2}{*}{$\begin{array}{c}\text { Statically } \\
\text { significance } \\
\& \\
\text { Sentence } \\
\text { Content }\end{array}$} & \multicolumn{2}{|r|}{$\stackrel{0}{\infty}$} & \multicolumn{2}{|c|}{ 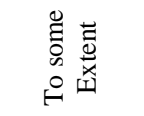 } & \multicolumn{2}{|c|}{$\stackrel{\circ}{Z}$} & \multirow{2}{*}{ 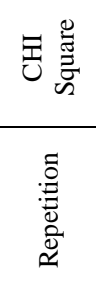 } & \multirow{2}{*}{ 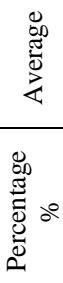 } & \multirow{2}{*}{ 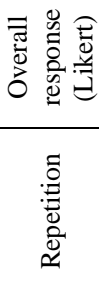 } & \multirow{2}{*}{ 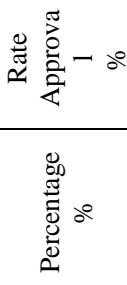 } \\
\hline & & : & 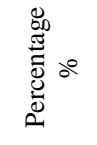 & : & 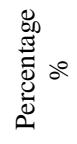 & :0 & 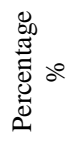 & & & & \\
\hline \multirow{3}{*}{ 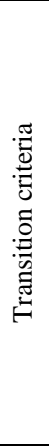 } & $\begin{array}{l}\text { Improved } \\
\text { respiratory } \\
\text { endurance } \\
\text { and lower } \\
\text { endurance. }\end{array}$ & o. & $1 \cdots \cdots$ & $\cdot$ & $\because \cdots$ & • & $\because \cdot$ & $\because \cdots$ & r... & Yes & $1 \cdots \cdots$ \\
\hline & $\begin{array}{c}\text { Improved } \\
\text { fixed strength } \\
\text { of the femoral } \\
\text { front muscles. }\end{array}$ & 0 . & $1 \ldots \cdots$ & · & $\because \cdots$ & · & $\because \cdots$ & $\because \cdots$ & $r . .$. & Yes & $1 \cdots \cdots$ \\
\hline & $\begin{array}{l}\text { Improved } \\
\text { fixed strength } \\
\text { of the } \\
\text { posterior } \\
\text { thigh } \\
\text { muscles. }\end{array}$ & o. & $1 \cdots \cdots$ & · & $\because \cdots$ & · & $\because \cdots$ & $\because \cdots$ & $r . .$. & Yes & $1 \cdots \cdots$ \\
\hline \multirow{5}{*}{ 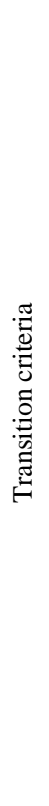 } & $\begin{array}{l}\text { Improves } \\
\text { the fixed } \\
\text { force of the } \\
\text { distal } \\
\text { muscles of } \\
\text { the thigh. }\end{array}$ & o. & $1 \ldots \cdots$ & $\cdot$ & $\because \cdots$ & · & $\because \cdots$ & $\because \cdots$ & r... & Yes & $1 \ldots$ \\
\hline & $\begin{array}{l}\text { Improve the } \\
\text { motor range } \\
\text { to extend } \\
\text { joints } 15^{\circ} \text {. }\end{array}$ & o. & $1 \cdots \cdots$ & $\cdot$ & $\because \cdots$ & • & $\because \cdots$ & $\because \cdots$ & r... & Yes & $1 \cdots \cdots$ \\
\hline & $\begin{array}{c}\text { Load at } \\
\text { least } 75 \% \text { of } \\
\text { the body } \\
\text { weight of } \\
\text { the infected } \\
\text { leg. }\end{array}$ & $\leq r$ & ^ч... & 0 & $1 \cdot \ldots$ & r & $\varepsilon$. & *ฯ צ. & $r . \wedge r$ & Yes & $91 .$. \\
\hline & $\begin{array}{c}\text { Improved } \\
\text { stable } \\
\text { balance on } \\
\text { infected leg. }\end{array}$ & o. & $1 \cdots$ & $\cdot$ & $\because \cdots$ & · & $\because \cdots$ & $\because \cdots$ & r... & Yes & $1 \cdots \cdots$ \\
\hline & $\begin{array}{l}\text { Improved } \\
\text { walking } \\
\text { speed for } \\
\text { front and } \\
\text { back }\end{array}$ & 0. & $1 \cdots \cdots$ & $\cdot$ & $\because \cdots$ & $\cdot$ & $\because \cdots$ & $\because \cdots$ & r... & Yes & $1 \cdots \cdots$ \\
\hline
\end{tabular}


Follow Table (3)

Frequency, percentage and statistical significance of the third qualifying stage

\begin{tabular}{|c|c|c|c|c|c|c|c|c|c|c|c|}
\hline \multirow{2}{*}{ Sr. } & \multirow{2}{*}{$\begin{array}{c}\text { Statically } \\
\text { significance } \\
\& \\
\text { Sentence } \\
\text { Content }\end{array}$} & \multicolumn{2}{|r|}{$\stackrel{\Delta}{\Delta}$} & \multicolumn{2}{|c|}{ 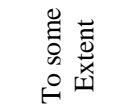 } & \multicolumn{2}{|c|}{$\stackrel{0}{\text { Z }}$} & \multirow{2}{*}{ 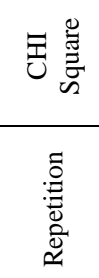 } & \multirow{2}{*}{ 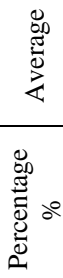 } & \multirow{2}{*}{ 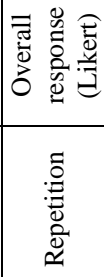 } & \multirow{2}{*}{ 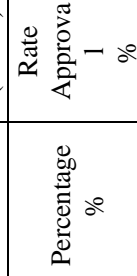 } \\
\hline & & 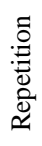 & 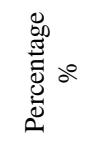 & 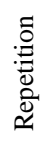 & 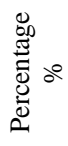 & 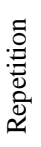 & 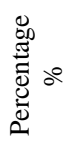 & & & & \\
\hline & $\begin{array}{l}\text { Improves } \\
\text { the } \\
\text { performance } \\
\text { of use the } \\
\text { stairs } \\
\text { without } \\
\text { relying. }\end{array}$ & 0. & $1 \cdots$ & $\cdot$ & $\because \cdots$ & • & $\because \cdots$ & $\because \cdots$ & $r_{.}$. & Yes & $1 \cdots$ \\
\hline \multirow{5}{*}{ 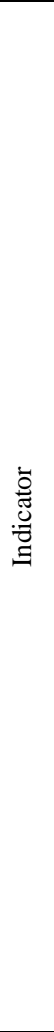 } & $\begin{array}{l}\text { Performance } \\
\text { on } \\
\text { stationary } \\
\text { bike for } 10 \mathrm{~s} \\
\text { connected. }\end{array}$ & 0. & $1 \cdots$ & • & $\because \cdots$ & • & $\because \cdots$ & $\because \cdots$ & $r . \cdot$ & Yes & $1 \cdots \cdots$ \\
\hline & $\begin{array}{c}\text { Lift the } \\
\text { weight of } \\
\text { the weight } \\
15 \mathrm{~kg} \text { and } \\
\text { the stability } \\
\text { of } 15 \mathrm{w} \\
\text { using the } \\
\text { front device. }\end{array}$ & $\leq \varepsilon$ & $\wedge \wedge .$. & $\varepsilon$ & $\wedge_{.} \cdot$ & $r$ & $\{. \cdots$ & * & 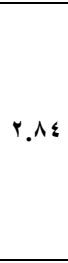 & Yes & qr... \\
\hline & $\begin{array}{l}\text { Lift the } \\
\text { weight of its } \\
\text { weight } 10 \\
\mathrm{~kg} \text { and } \\
\text { fasten } 15 \mathrm{w} \\
\text { using the } \\
\text { background } \\
\text { device. }\end{array}$ & $\varepsilon r$ & Av.Vฯ & $\varepsilon$ & 1.17 & $r$ & $\varepsilon .1$ & $* 40 . \leqslant r$ & 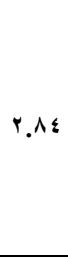 & Yes & $91 . \wedge \leq$ \\
\hline & $\begin{array}{c}\text { Weighing } \\
\text { weight of } 10 \\
\text { kg and } \\
\text { stability } 15 \\
\text { w by using } \\
\text { the braces. }\end{array}$ & $\leqslant 9$ & १^... & 1 & $r_{.}$. & • & $\because \cdots$ & $* \leq 7 . \cdot 1$ & r.91 & Yes & $99 . \cdots$ \\
\hline & $\begin{array}{c}\text { Increase the } \\
\text { angle of } \\
\text { joints by } 15 \\
\text { degrees } \\
\text { using the }\end{array}$ & $\leqslant 9$ & $9 \wedge .$. & 1 & $r_{.} \cdot$. & $\cdot$ & $\because \cdots$ & $* \leq 7 . * 1$ & r.91 & Yes & $99 . \ldots$ \\
\hline
\end{tabular}




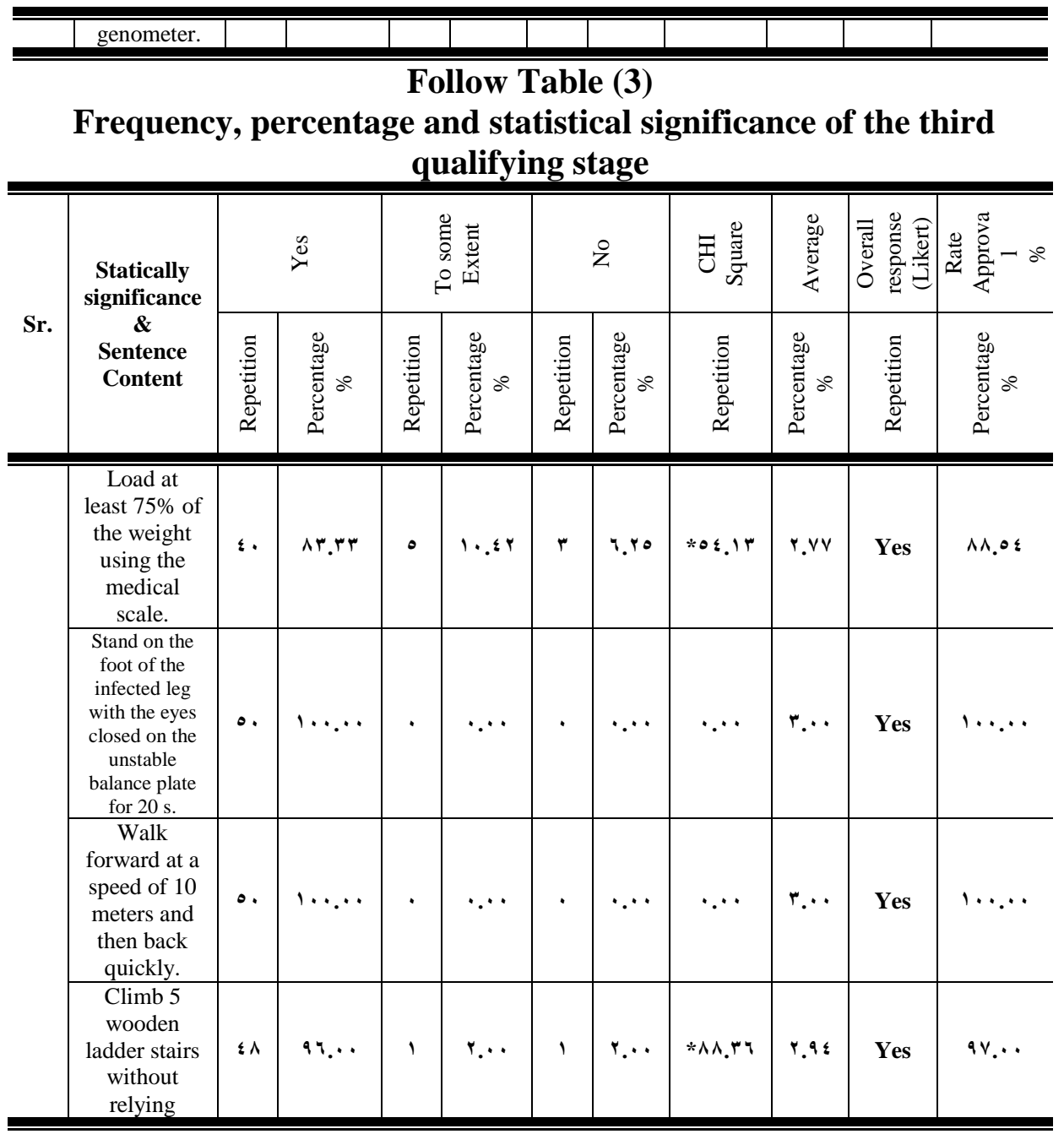

Likert scale: average weight: - 1.00-1.66 (no), 1.67-2.33 (to some extent), 2.34-3.00 (yes)

Table (2): Frequency, percentage and statistical significance of the second qualification stage showed significant differences between the responses and the values of the CI at 0.05 level in some physical qualification and verification criteria. The percentage ranged from $87.00 \%$ to $100.00 \%$ ).

The increase in the number and quality of qualification criteria is evident by increasing the degree or time in a specific way or by reducing the aids. The standards have started to move towards the performance 
of functional movements according to the degree of disability. Where the duties of good physical rehabilitation to identify the capabilities of disabled, which can predict the level that can be achieved during the stages of qualification. The need to develop standards due to different disabilities and a function of physical, mental and psychological preparation. It has become recognized that the possibility of disabled access to levels If possible from the beginning of proper rehabilitation, to the appropriate targets that fit their preparedness and capabilities and accurately predict the impact of rehabilitation processes on the growth and development of those standards

Table (4)

and indicators of verification in an effective manner.

*A significant $\mathrm{CHI}$ square at level 0.05 where the significance level 0.050 .05 at the degree of freedom $2=5.99$, the degree of freedom $1=3.84$ Likert scale: average weight: $1.00-1.66$ (no), $1.67-2.33$ (to a certain extent), 2.34-3.00 (yes), shown in Table (3) for frequency, percentage and statistical indications of the third qualifying stage, There were significant differences between the responses and these values for a significant $\mathrm{CHI}$ square at level 0.05 in some physical qualification criteria and phase verification indicators, with a percentage of approval ranging from $(88.54 \%$ to $100.00 \%$ ).

\section{Frequency, percentage and statistical indications of the fourth} qualifying stage

\begin{tabular}{|c|c|c|c|c|c|c|c|c|c|c|c|}
\hline \multirow[b]{2}{*}{ Sr. } & \multirow{2}{*}{$\begin{array}{c}\text { Statically } \\
\text { significance } \\
\& \\
\text { Sentence } \\
\text { Content }\end{array}$} & \multicolumn{2}{|r|}{ 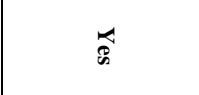 } & \multicolumn{2}{|c|}{ 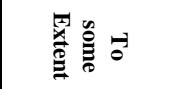 } & \multicolumn{2}{|c|}{$z$} & \multirow{2}{*}{ 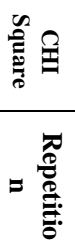 } & \multirow{2}{*}{ 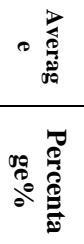 } & \multirow{2}{*}{ 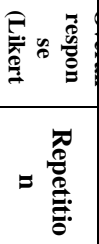 } & \multirow{2}{*}{ 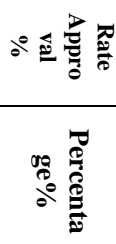 } \\
\hline & & $=\frac{\pi}{\stackrel{\pi}{0}}$ & 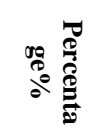 & $=\frac{\pi}{\frac{\pi}{0}}$ & a & $=\frac{\underset{0}{0}}{0}$ & 要 & & & & \\
\hline \multirow[t]{2}{*}{ 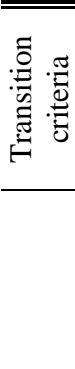 } & $\begin{array}{l}\text { Improved } \\
\text { respiratory } \\
\text { endurance } \\
\text { and lower } \\
\text { endurance. }\end{array}$ & 0 . & $1 \ldots$. & - & $\because \cdots$ & - & $\because \cdots$ & $\because \cdots$ & $r .$. & Yes & $1 \cdots \cdots$ \\
\hline & $\begin{array}{l}\text { Improved } \\
\text { the moving } \\
\text { force of the } \\
\text { front thigh } \\
\text { muscles. }\end{array}$ & 0 . & $1 \ldots \ldots$ & - & $\because \cdots$ & . & $\because \cdots$ & $\because \cdots$ & r... & Yes & $1 \ldots \cdots$ \\
\hline
\end{tabular}


FollowTable (4)

Frequency, percentage and statistical indications of the fourth qualifying stage

\begin{tabular}{|c|c|c|c|c|c|c|c|c|c|c|c|}
\hline \multirow[b]{2}{*}{ Sr. } & \multirow{2}{*}{$\begin{array}{c}\text { Statically } \\
\text { significance } \\
\& \\
\text { Sentence } \\
\text { Content }\end{array}$} & \multicolumn{2}{|r|}{ 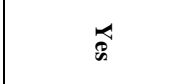 } & \multicolumn{2}{|c|}{ 㺼 } & \multicolumn{2}{|c|}{$z$} & \multirow{2}{*}{ 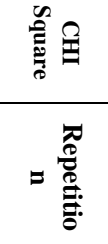 } & \multirow{2}{*}{ 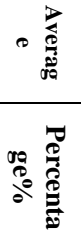 } & \multirow{2}{*}{ 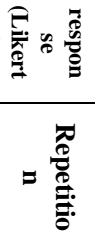 } & \multirow{2}{*}{ 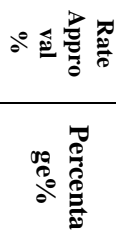 } \\
\hline & & $=\frac{\pi}{\stackrel{\pi}{8}}$ & 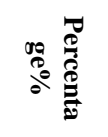 & $=\frac{\pi}{\stackrel{2}{8}}$ & ac & $=\frac{\pi}{0}$ & 要 & & & & \\
\hline & $\begin{array}{c}\text { Improved } \\
\text { mobile force of } \\
\text { the posterior } \\
\text { thigh muscles. }\end{array}$ & $\leq 9$ & $9 \wedge .$. & 1 & r... & . & $\because \cdots$ & $* \leqslant 4.1$ & r.91 & Yes & $99 . \cdots$ \\
\hline & $\begin{array}{l}\text { Improve the } \\
\text { mobility of } \\
\text { the thigh } \\
\text { muscles. }\end{array}$ & 0. & $1 \cdots \ldots$ & . & $\because \cdots$ & . & $\because \cdots$ & $\because \cdots$ & $r .$. & Yes & $1 \cdots$, \\
\hline & $\begin{array}{l}\text { Improve the } \\
\text { motor range } \\
\text { to extend } \\
\text { joints } 15^{\circ} \text {. }\end{array}$ & 0. & $1 \cdots \ldots$ & - & $\because \cdots$ & - & $\because \cdot$ & $\because \cdots$ & $r .$. & Yes & $1 \cdots \ldots$ \\
\hline & $\begin{array}{l}\text { Load the } \\
\text { entire body } \\
\text { weight on } \\
\text { both legs. }\end{array}$ & rᄉ & $v_{7} . \cdots$ & 9 & $11 .$. & $r$ & $7 . \cdots$ & $* \varepsilon r_{.} \cdot \varepsilon$ & $r . v$. & Yes & 10... \\
\hline & $\begin{array}{c}\text { Improved } \\
\text { moving } \\
\text { balance. }\end{array}$ & 0. & $1 \ldots$. & . & $\because \cdots$ & . & $\because \cdots$ & $\because \cdots$ & $r .$. & Yes & $1 \cdots \ldots$ \\
\hline & $\begin{array}{l}\text { Improved } \\
\text { walking } \\
\text { speed for } \\
\text { front and } \\
\text { back }\end{array}$ & $\varepsilon \wedge$ & $97 .$. & r & $\varepsilon .$. & . & $\because \cdots$ & $* \varepsilon Y, r T$ & r.97 & Yes & $91 .$. \\
\hline & $\begin{array}{l}\text { Improved } \\
\text { walking } \\
\text { speed for } \\
\text { front, back, } \\
\text { right, left. }\end{array}$ & $\varepsilon 9$ & $91 .$. & . & $\because \cdots$ & 1 & $r_{.}$. & $* \leqslant 7 . \cdot 1$ & r.97 & Yes & $91 .$. \\
\hline & $\begin{array}{c}\text { Ability to } \\
\text { hobble on } \\
\text { infected leg } \\
\text { in place. }\end{array}$ & 0. & $1 \cdots \ldots$ & . & $\because \cdots$ & . & $\because \cdots$ & $\because \cdots$ & r... & Yes & $1 \ldots \ldots$ \\
\hline \multirow[t]{2}{*}{ 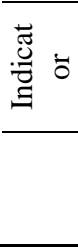 } & $\begin{array}{c}\text { Performance } \\
\text { on stationary } \\
\text { bike for } 15 \mathrm{~s} \\
\text { connected. }\end{array}$ & 0. & $1 \cdots$ & . & $\because \cdots$ & . & $\because \cdots$ & $\because \cdots$ & $r .$. & Yes & $1 \cdots \cdots$ \\
\hline & $\begin{array}{l}\text { Performance on } \\
\text { the bike weight } \\
15 \mathrm{~kg} \text { and } \\
\text { repetition } 10\end{array}$ & $\leqslant 9$ & $91 .$. & 1 & $r_{.} . \cdot$ & . & $\because \cdots$ & $* \leqslant 7 . \cdot 1$ & r.91 & Yes & $99 .$. \\
\hline
\end{tabular}




\section{Follow Table (4)}

Frequency, percentage and statistical indications of the fourth qualifying stage

\begin{tabular}{|c|c|c|c|c|c|c|c|c|c|c|c|}
\hline \multirow{2}{*}{ Sr. } & \multirow{2}{*}{$\begin{array}{c}\text { Statically } \\
\text { significance } \\
\& \\
\text { Sentence } \\
\text { Content }\end{array}$} & \multicolumn{2}{|r|}{$\overparen{\&}$} & \multicolumn{2}{|c|}{ 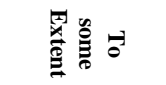 } & \multicolumn{2}{|c|}{$z$} & \multirow{2}{*}{ 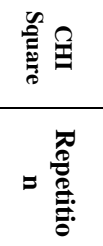 } & \multirow{2}{*}{ 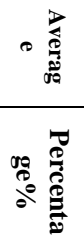 } & \multirow{2}{*}{ 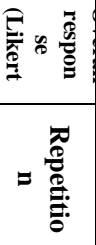 } & \multirow{2}{*}{ 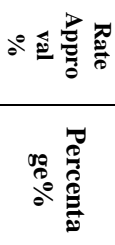 } \\
\hline & & 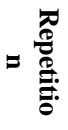 & 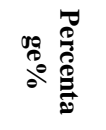 & 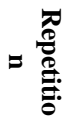 & & 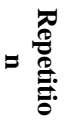 & a & & & & \\
\hline & & & & & & & & & & & \\
\hline & $\begin{array}{c}\text { Using a } \\
\text { backdrop, lift } \\
\text { the weight of } \\
10 \mathrm{~kg} \text { and } \\
\text { repeat } 10 \\
\text { counts. }\end{array}$ & $\varepsilon \Lambda$ & $9 \vee .97$ & 1 & $r . \varepsilon$ & • & $\because \cdots$ & $* \leqslant 0.1$ & r.91 & Yes & $9 \wedge .9 \wedge$ \\
\hline & $\begin{array}{l}\text { Using the } \\
\text { stenting device, } \\
\text { the weight of } \\
\text { its weight is } 10 \\
\mathrm{~kg} \text { and the } \\
\text { repetition } 10 .\end{array}$ & $\leqslant 9$ & $91 .$. & 1 & $r .$. & · & $\because \cdots$ & $* \leq 7 . \wedge$ & r.91 & Yes & $99 . \ldots$ \\
\hline & $\begin{array}{l}\text { Increase the } \\
\text { angle of joints } \\
\text { by } 15 \text { degrees } \\
\text { using the } \\
\text { genometer. }\end{array}$ & 0. & $1 \ldots$ & • & $\because \cdots$ & • & $\because \cdots$ & $\because \cdots$ & r... & Yes & $1 \cdots \cdots$ \\
\hline & $\begin{array}{l}\text { Load the entire } \\
\text { body weight on } \\
\text { both legs using } \\
\text { the medical } \\
\text { scale. }\end{array}$ & $\leqslant 1$ & Ar... & 7 & Ir... & r & $7 . \cdots$ & *or.07 & $r . V T$ & Yes & $\wedge \wedge .$. \\
\hline & $\begin{array}{l}\text { Walk forward } \\
\text { on a drawn line } \\
\text { on the ground } \\
\text { with the eyes } \\
\text { closed for } 5 \\
\text { meters }\end{array}$ & $\varepsilon$. & $\wedge .$. & V & $1 \varepsilon \ldots$ & r & $7 . \cdots$ & $* \leqslant q . \leqslant \wedge$ & $r . V \varepsilon$ & Yes & Av... \\
\hline & $\begin{array}{c}\text { Walk quickly at } \\
10 \text { meters } \\
\text { forward, back, } \\
\text { right, left }\end{array}$ & $\leqslant 9$ & $1 \ldots$ & - & $\because \cdots$ & • & $\because \cdots$ & $\because \cdots$ & $r .$. & Yes & $1 \cdots \cdots$ \\
\hline & $\begin{array}{c}\text { Running in } \\
\text { place for } 2 \mathrm{~s} 3 \\
\text { times at } \\
\text { moderate speed } \\
30 \mathrm{~s} .\end{array}$ & $\varepsilon \Lambda$ & $97 .$. & 1 & $r .$. & 1 & r... & 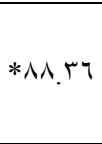 & r. $9 \varepsilon$ & Yes & $9 \vee . .$. \\
\hline & $\begin{array}{c}\text { hobble on } \\
\text { infected leg in } \\
\text { place for } 1 \mathrm{~s} 3 \\
\text { times rest } 20 \mathrm{w} .\end{array}$ & 0 . & $1 \ldots$ & • & $\because \cdots$ & • & $\because \cdots$ & $\because \cdots$ & $r .$. & Yes & $1 \cdots \cdots$ \\
\hline
\end{tabular}


*CHI Square is significant at 0.05 where the significance level is 0.05 0.05 at the degree of freedom $2=5.99$, the degree of freedom $1=$ 3.84, the Likert scale: weighted average arithmetic weights: $-1.00-1.66$ (no), 1.67-2.33 (to a certain extent), 2.34 (3).

It is clear from Table (4) that there are significant differences between the responses and these values for a significant Chi Square at level 0.05 in some physical qualification and verification criteria, with a percentage of approval ranging from $85.00 \%$ to $100.00 \%$.

\section{Table (5)}

\section{Frequency, percentage and statistical significance of the} fifth qualifying stage

\begin{tabular}{|c|c|c|c|c|c|c|c|c|c|c|c|}
\hline & \multirow{2}{*}{$\begin{array}{c}\text { Statically } \\
\text { significance } \\
\& \\
\text { Sentence } \\
\text { Content }\end{array}$} & \multicolumn{2}{|r|}{ 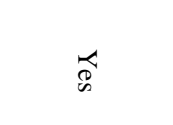 } & \multicolumn{2}{|c|}{ 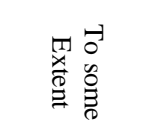 } & \multicolumn{2}{|c|}{ z } & \multirow{2}{*}{ 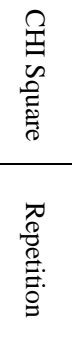 } & \multirow{2}{*}{ 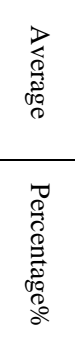 } & \multirow{2}{*}{ 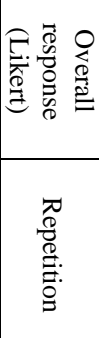 } & \multirow{2}{*}{ 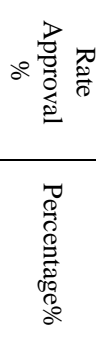 } \\
\hline & & 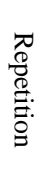 & 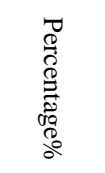 & 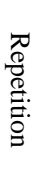 & 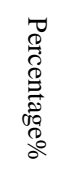 & 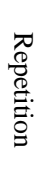 & 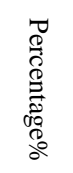 & & & & \\
\hline \multirow{3}{*}{ 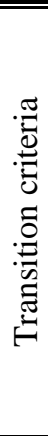 } & $\begin{array}{c}\text { Improved } \\
\text { respiratory } \\
\text { endurance and } \\
\text { lower } \\
\text { endurance. } \\
\end{array}$ & 0 . & $1 \ldots$ & . & $\because \cdots$ & · & $\because \cdots$ & $\because \cdots$ & r... & Yes & $1 \cdots$ \\
\hline & $\begin{array}{l}\text { Improved the } \\
\text { moving force } \\
\text { of the front } \\
\text { thigh muscles. }\end{array}$ & 0 . & $1 \cdots$ & · & $\because \cdots$ & · & $\because \cdots$ & $\because \cdots$ & r... & Yes & $1 \cdots$ \\
\hline & $\begin{array}{l}\text { Improved } \\
\text { mobile force of } \\
\text { the posterior } \\
\text { thigh muscles. }\end{array}$ & $\leqslant 9$ & $1 \cdots$ & $\cdot$ & $\because \cdots$ & $\cdot$ & $\because \cdots$ & $\because \cdots$ & r... & Yes & $1 \cdots$ \\
\hline \multirow{4}{*}{ 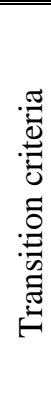 } & $\begin{array}{l}\text { Improve the } \\
\text { mobility of the } \\
\text { thigh muscles. }\end{array}$ & 0 . & $1 \cdots$ & · & $\because \cdots$ & · & $\because \cdots$ & $\because \cdots$ & r... & Yes & $1 \cdots$ \\
\hline & $\begin{array}{l}\text { Access to the } \\
\text { full range of } \\
\text { joints of } 95 \% \\
\text { of healthy leg. }\end{array}$ & 0. & $1 \cdots$ & . & $\because \cdots$ & $\cdot$ & $\because \cdots$ & $\because \cdots$ & r... & Yes & $1 \cdots$ \\
\hline & $\begin{array}{l}\text { Improve the } \\
\text { movement and } \\
\text { speed of running } \\
\text { forward. }\end{array}$ & 0. & $1 \cdots$ & • & $\because \cdots$ & $\cdot$ & $\because \cdots$ & $\because \cdots$ & r... & Yes & $1 \cdots$ \\
\hline & $\begin{array}{l}\text { Ability to leap } \\
\text { forward with }\end{array}$ & 0. & $1 \cdots \cdot$ & . & $\because \cdots$ & · & $\because \cdots$ & $\because \cdots$ & r... & Yes & $1 \cdots$ \\
\hline
\end{tabular}




\begin{tabular}{c|c|c|c|c|c|c|c|c|c|c|c}
\hline \hline & feet. & & & & & & & & & & \\
\hline $\begin{array}{c}\text { Ability to triple } \\
\text { jump (hop } \\
\text { step) forward. }\end{array}$ & 0. & $1 \ldots \cdot$ &. & $\ddots \cdots$ &. & $\ddots \ldots$ & $\ddots \ldots$ & $\varphi_{.} .$. & Yes & $1 \ldots$ \\
\hline \hline
\end{tabular}

Table (5)

Frequency, percentage and statistical significance of the fifth qualifying stage

\begin{tabular}{|c|c|c|c|c|c|c|c|c|c|c|c|}
\hline & \multirow{2}{*}{$\begin{array}{c}\text { Statically } \\
\text { significance } \\
\& \\
\text { Sentence } \\
\text { Content }\end{array}$} & \multicolumn{2}{|c|}{$\underset{8}{\varnothing}$} & \multicolumn{2}{|c|}{ 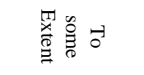 } & \multicolumn{2}{|c|}{ z } & \multirow{2}{*}{ 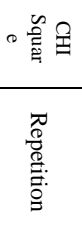 } & \multirow{2}{*}{ 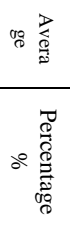 } & \multirow{2}{*}{ 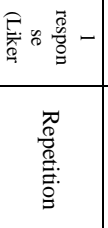 } & \multirow{2}{*}{ 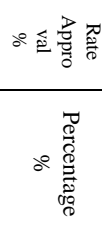 } \\
\hline & & 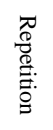 & 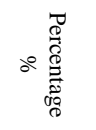 & 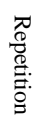 & 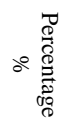 & 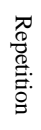 & 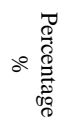 & & & & \\
\hline \multirow{10}{*}{ 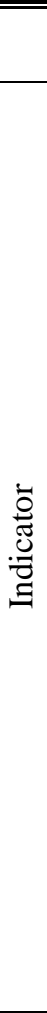 } & $\begin{array}{l}\text { Ability to hobble on } \\
\text { infected leg } \\
\text { forward. }\end{array}$ & $\varepsilon q$ & $1 \cdots$ & - & $\because \cdots$ & - & $\because \cdots$ & $\because \cdots$ & $r .$. & Yes & $1 \cdots$ \\
\hline & $\begin{array}{l}\text { Running on the } \\
\text { Treadmill for } 12 \\
\text { seconds is } \\
\text { connected to a m- } \\
\text { speed. }\end{array}$ & 0. & $1 \cdots$ & - & $\because \cdots$ & - & $\because \cdots$ & $\because \cdots$ & $r .$. & Yes & $1 \cdots$ \\
\hline & $\begin{array}{c}\text { Lift weight } 20 \mathrm{~kg} \\
\text { and repeat } 15 \text { tools } \\
\text { using the front } \\
\text { device. }\end{array}$ & 0. & $1 \cdots$ & - & $\because \cdots$ & - & $\because \cdots$ & $\because \cdots$ & $r .$. & Yes & $1 \cdots$ \\
\hline & $\begin{array}{l}\text { Lift weight } 15 \mathrm{~kg} \\
\text { and repeat } 15 \text { tools } \\
\text { using the back } \\
\text { device. } \\
\end{array}$ & 0. & $1 \cdots$ & - & $\because \cdots$ & • & $\because \cdots$ & $\because \cdot$ & r... & Yes & $1 \cdots$ \\
\hline & $\begin{array}{l}\text { The weight is } 15 \mathrm{~kg} \\
\text { and the repetition is } \\
15 \text { tools }\end{array}$ & 0. & $1 \cdots$ & - & $\because \cdots$ & - & $\because \cdots$ & $\because \cdot$ & r... & Yes & $1 \cdots$ \\
\hline & $\begin{array}{l}\text { Comparison of the } \\
\text { angle of the affected } \\
\text { joints with the } \\
\text { correct knee flexion } \\
\text { of the genometer. }\end{array}$ & 0. & $1 \cdots$ & - & $\because \cdot$ & • & $\because \cdots$ & $\because \cdots$ & $r .$. & Yes & $1 \cdots$ \\
\hline & $\begin{array}{l}\text { Running around the } \\
\text { football field } 7 \text { rolls } \\
\text { - average of } 70 \% \text { of } \\
\text { the speed }\end{array}$ & 0. & $1 \cdots$ & - & $\because \cdots$ & • & $\because \cdots$ & $\because \cdot$ & $r .$. & Yes & $1 \cdots$ \\
\hline & $\begin{array}{c}\text { The wide-legged } \\
\text { jump is two meters } \\
\text { away. }\end{array}$ & $\leqslant 9$ & $1 \cdots$ & - & $\because \cdots$ & • & $\because \cdots$ & $\because \cdot$ & r... & Yes & $1 \cdots$ \\
\hline & $\begin{array}{c}\text { Triple jump (dart- } \\
\text { hop step) of stability } \\
\text { forward } 4 \text { meters } \\
\text { distance. }\end{array}$ & 0. & $1 \cdots$ & - & $\because \cdots$ & - & $\because \cdots$ & $\because \cdots$ & $r .$. & Yes & $1 \cdots$ \\
\hline & $\begin{array}{c}\text { Hobble on the } \\
\text { infected leg from } \\
\text { the stability of the } \\
\text { forward distance of } \\
10 \text { meters. }\end{array}$ & 0. & $1 \cdots$ & - & $\because \cdots$ & • & $\because \cdots$ & $\because \cdot$ & $r .$. & Yes & $1 \cdots$ \\
\hline
\end{tabular}

*A significant CHI Square at level 0.05 where the significance level 0.050 .05 at the degree of freedom $2=5.99$, the degree of freedom $1=$ 3.84 
Likert scale: Weighted mean weight: - 1.00-1.66 (no), 1.67-2.33 (to some extent), 2.34-3.00 (yes)

1. Table 5 shows the frequency, percentage and statistical significance of the fifth qualification stage. There were no significant differences between the responses, with an approval rate of $(100.00 \%)$ in all physical qualification criteria and verification indicators.

2. Based on the previous table presentation, determining the physical qualification criteria will allow the handicapped and the physical rehabilitation specialist to recognize their relative position during the rehabilitation process. This is an important and necessary measure to achieve the ideal evaluation. It should also be noted that the criteria are not optimum levels that we seek. The center of relative disability also contributes to determining what level reached (1) (3). The existence of a strong support system inside and outside rehabilitation is based on clear and specific criteria, which is the key to building the confidence of the disabled in achieving a rearrangement of priorities after disability. The criteria for returning to individual capacities after functional disability are often based on the "satisfactory" In previous reference studies (7). For example, Study No. 16 modified three standard performance tools in the areas of general fitness (2-minute walking test), balance and walking (positive mobility assessment), and functional independence (Bartel adjusted index). They confirmed that modified tools provide physicians with quantitative measures to track changes in physical performance of infected persons. Performance criteria are the levels at which performance is satisfactory; the choice of these criteria is essential for the successful implementation of the performance evaluation. It also contributes to the support of the rehabilitation department in the selection of therapeutic exercises and rehabilitation tools that help to develop overall functional performance. In the future, therapists should recognize the many benefits of using technology in rehabilitation. Technology can 
be used to achieve benefit as an adjunct to exercise therapy, to evaluate and monitor patient performance to ensure quality and quantity of movements to heal, an investment of time and a customized approach to meet individual patient needs. Technology developers to improve the design of standards and indicators that enable the use of technologies to better support the rehabilitation of functional disabilities.

\section{Conclusions:}

3. The total number of physical qualification criteria and indicators in the five stages reached 36 criteria and indicators, the first phase 3 criteria and 3 indicators, the second phase reached 5, the third stage 9 , the fourth stage 10 , the fifth phase amounted to 9 standards and 9 indicators.

4. Qualifying criteria and indicators developed during the rehabilitation stages and increased the difficulty and number in line with the objectives of the therapeutic exercises, and gradually evolved to include fixed performances and transitional performances to reach the functional performance.
5. The percentage of approval of the research sample ranged from $85.00 \%$ to $100.00 \%$. This indicates that there are no significant differences between the sample responses and confirms the credibility and stability of the physical qualification criteria and the indicators of measurement in question, and it can be relied upon to move from one stage of rehabilitation to another.

6. Indicators of physical rehabilitation standards designed during the stages of the program of therapeutic exercises enables the rehabilitation specialist to obtain degrees expressing the elements of physical rehabilitation of the strength of muscle and fixed mobility, load body weight, speed characteristic, fixed balance and moving, sense of movement, speed, Endurance.

\section{Recommendations:}

1. There is an urgent need to design criteria to assess the strength of the muscles of the handicapped functionally during the same motor activities that the disabled person needs to return to normal life. 
2. Dependence on sophisticated measuring devices when analyzing functional motor tasks to provide us with more accurate data and enable us to improve the efficiency of rehabilitation in terms of time and effectiveness.

3. Starting the study of criteria and indicators of quantitative measurement of functional disabilities early to stand on the causes of imbalances leading to motor disability, which contributes to the efficiency of the design of future rehabilitation programs.

4. Some psychosocial criteria, including frequency, distrust and fear of braking, which are directly related to the function of the affected part, as well as other factors independent of physical function such as changes in priorities or expectations, relevant to the relationship between the patient and rehabilitation, and affecting the decision to return to The practice of normal life to a large extent

5. .The criteria and their verification indicators shall be applied in a multi-year standardized procedure on a large sample of persons with functional disabilities so that we can represent these standards with standard values parallel to the raw values derived from the tests, which will help us to make the decisions of the amendment in the goals and programs of the therapeutic exercises.

\section{Arabic References}

\section{1- Ahmed Abdel-Fattah}

Omran: Effect of a physical training program on the degree of limp during the transitional movements of a young footballer with fractured femur fracture. Qir, University of Alexandria, during the period from 15 - 17 October 2008.

2- Ahmed Ali Saleh: evidence in the back pain and alternative medicine, Madbouli Library for printing and publishing, the first edition, Cairo, 2009.

3- Mohammed Jaber Bareeqa, Ahmed Abdel Fattah Omran: Effect of rehabilitation program on some kinematic variables associated with functional motor disability after surgical repair of lateral fracture of femur, patella fracture and lateral lateral ligament rupture (case study $100 \mathrm{~m}$ runner) And Applications "Faculty of Physical Education 
for Boys in Abu Qir, Alexandria University, January 2013.

\section{Foreign References}

1- Ishehri MA, Alhasan H, Alayat M, Al- Subahi M, Yaseen K, Ismail A, Tobaigy A, Almalki O, Alqahtani A, Fallata B. Factors affecting the extent of utilization of physiotherapy services by physicians in Saudi Arabia. J Phys Ther Sci. 2018 Feb; 30 (2): 216-222.

2- Bednar DA, Ali P. Intramedullary nailing of femoral shaft fractures: reoperation and return to work. Can J Surg. 1993;36: 464-466.

3- Bucher JL, MacKenzie EJ, Cushing B, et al. Long-term outcomes after lower extremity trauma. J Trauma. 1996;41:49.

4- Burland JP, Toonstra J, Werner JL, Mattacola CG, Howell DM, Howard JS. Decision to Return to Sport After Anterior Cruciate Ligament Reconstruction, Part I: A Qualitative Investigation of Psychosocial Factors. J Athl Train. 2018 Mar 5. doi: 10.4085/1062-6050-313

\section{5- Christian A, González-} Fernández M, Mayer RS, Haig AJ. Rehabilitation needs of persons discharged from an
African trauma center, Pan Afr Med J. 2011;10:32. Epub 2011 Nov 7.

6- Dalal K, Lin Z, Gifford M, Svanstrom L. Economics of global urdenr of road traffic injuries and their relationship with health system variables. Int J Prev Med. 2013; 4 (12):1442-50.

7- Hamilton C, Lovarini M, McCluskey A, Folly de Campos T, Hassett L. Experiences of therapists using feedback-based technology to improve physical function in rehabilitation settings: a qualitative systematic review. Disabil Rehabil.2018Mar7:112.

8- Helander E, ed. Prejudice

\& Dignity: An Introduction to Community-Based

Rehabilitation. 2nd, 1999 ed. United Nations Development Programs (UNDP); 1993.

9- Jurkovich G, Mock C, MacKenzie E, et al. The Sickness Impact Profile as a tool to evaluate functional outcome in trauma patients. J Trauma. 1995;39:625-631.

10- Kapp W, Lindsey RW, Noble PC, et al. Long-term residual musculoskeletal deficits after femoral shaft fractures treated with 
intramedullary nailing. $\mathbf{J}$ Trauma. 2000;49:446 - 449.

\section{1- Leggon RE, Feldmann} DD. Retrograde femoral nailing: a focus on the knee. Am J Knee Surg. 2001;14:109118.

\section{2- Lightsey HM, Kantrowitz} DE, Swindell HW, Trofa DP, Ahmad CS, Lynch TS. Variability of United States Online Rehabilitation Protocols for Proximal Hamstring Tendon Repair. Orthop J Sports Med. 2018 Feb 23;6 (2):232

13- Maring JR, Costello E, Birkmeier MC, Richards M, Alexander LM. Validating functional measures of physical ability for aging people with intellectual developmental disability, Am J Intellect Dev Disabil. 2013. Mar;118(2):12440.

14- McCarthy J. J., Parker R. D. Arthroscopic reduction and internal fixation of a displaced intraarticular lateral femoral condyle fracture of the knee. Arthroscopy, 1996, 12, 224-227.

\section{5- Murray CJ, Vos T,} Lozano R, Naghavi M, Flaxman AD, Michaud C, et al. Disability-adjusted life years (DALYs) for 291 diseases and injuries in 21 regions, 1990-2010: a systematic analysis for the Global Burden of Disease Study 2010. Lancet. 2012; 380(9859):2197-223.

\section{6- Ogilvie R, McCloughen} A, Curtis K, Foster K. The experience of surviving lifethreatening injury: a qualitative synthesis. Int Nurs Rev. 2012; 59(3):312-20.

17- Ostrum RF, Agarwal A, Lakatos R, Poka A. Prospective comparison of retrograde and antegrade femoral intramedullary nailing. J Orthop Trauma. 2000; 14: 496-501.

18- Ostrum RF, DiCicco J, Lakatos R, Poka A. Retrograde intramedullary nailing of femoral diaphyseal fractures. J Orthop Trauma. 1998;12:464-468

19- Rasmussen R, Midttun M, Kolenda T, Ragle AM, Sørensen TW, Vinther A, Zerahn B, Pedersen M, Overgaard K. TherapistAssisted Progressive Resistance Training, Protein Supplements, and Testosterone Injections in Frail Older Men with Testosterone Deficiency: Protocol for a Randomized Placebo-Controlled Trial, 
JMIR Res Protoc. 2018 Mar 2; 7(3): 71.

20- Sabet F, Tabrizi K, Khankeh H, Saadat S, Abedi H, Bastami A. Road Traffic Accident Victims' Experiences of Return to Normal Life: A Qualitative Study. Iran Red Crescent Med J. 2016 April; 18(4): 29548.

21- Smith EJ, Crichlow TP, Roberts PS. Monocondylar fractures of the femur : A review of 13 patients. Injury, 1989, 20, 371-374.

22- Timm KE. Il ginocchio. In : Richardson J. K., Iglarsh Z. A., ed. Clinica Ortopedica. Terapia Fisica. Verduci Editore, Roma, 1996, pp. 405409.

23- Trandeeter HB.,
Shvertzman P., Stevens M A. Acute Knee Injuries: Use of
Decision Rules for Selective Radiograph Ordering, American Academy of Family Physicians, December,1999.

24- WHO: Disability including prevention, management, and rehabilitation. Available at http://www.who.int/nmh/a5817 /en/. Accessed March/14, 2011. 25- WHO: guidelines for essential trauma. Available at http://www.who.int/violence_i njury_prevention/publications/ services/guidelines_traumacare /en/index.html.Accessed March/14, 2011

26- Wolinsky P, Tejwani N, Richmond JH, et al. Controversies in intramedullary nailing of femoral shaft fractures. Instr Course Lect. 2002;51:291-303. 